\title{
FUERO Y JURISDICCIÓN ALFONSINOS EN LA GÉNESIS DE MUNICIPIOS VALENCIANOS
}

\author{
POR
}

\author{
ANTONIO GIL OLCINA
}

El denominado fuero alfonsino reviste especial interés por múltiples razones: creó una jurisdicción genuina, favoreció la unificación foral del reino de Valencia y, concluida ésta, perduró como instrumento de colonización interior. Reivindicado con esta última finalidad, y con la pretensión de extenderlo a toda España, por un influyente sector del reformismo borbónico tras la abolición de los Furs por Real Decreto de 29 de junio de 1707, fue el único de éstos restablecido y estuvo vigente hasta la promulgación del Decreto de Cortes de 6 de agosto de 1811, que declaró «incorporados a la Nación todos los señoríos jurisdiccionales, de cualquier clase y condición». Operativo durante más de cuatrocientos años, los que median entre 1329 y 1811 , salvo el paréntesis de 1707 a 1772, se afianzaron o surgieron a favor del mismo gran número de pequeños señoríos, convertidos luego casi todos ellos en municipios. Así, pues, el fuero alfonsino constituye clave interpretativa esencial e indispensable del mapa municipal valenciano. En efecto, el logro de la jurisdicción alfonsina, con independencia de que perdurase como tal hasta la disolución del régimen señorial o fuera reemplazada por la suprema o baronal, en la medida que motivó o fortaleció amojonamientos, actuó como un mecanismo frecuente y sumamente eficaz de fragmentación de términos generales ${ }^{1}$, tanto de realengo como señorío.

${ }^{1}$ Torres Faus, F.: Les divisions administratives històriques i l'ordenació del territori del País Valencià. València, Univ. de València, 1995, 3 vols. (tesis doctoral inédita).

Antonio Gil Olcina: Instituto Universitario de Geografía. Universidad de Alicante.

Estudios Geográficos

Tomo LX, n. ${ }^{\circ} 237$, octubre-diciembre 1999 


\section{Origen del fuero alfonsino}

Ante el serio riesgo de confrontación armada entre partidarios de los Furs y del Fuero de Aragón, códigos que coexisten en el reino de Valencia desde su conquista, Alfonso IV de Aragón y II de Valencia resolvió impulsar la unificación foral, favoreciendo la generalización de los Furs mediante una política de concesiones e incentivos; de ella nace el fuero alfonsino, acordado y otorgado en las Cortes reunidas en la capital el mes de noviembre de 1329.

Bajo la rúbrica De iuredictio atorgada a aquells qui nohan mer imperi, establecía el fuero, entre otras prescripciones, las siguientes: «Atorgam que prelats, persones ecclesiastiques, richs homens, cavallers, persones generoses, ciutadans e homens de viles qui no han mer imperi haien iuredictio civil e criminal e exercici conexença e derterminatio daquella: $E$ totes calonies e penes civils e criminals e drets daquelles en los lochs e alqueries lurs on stan o staran quinze casats o mes de crestians situades dins los termes de la ciutat, viles $e$ lochs del regne axi com daltres senyors qui consenten o consentran als presents furs o fora aquells termens de la ciutat, viles e lochs sobredits entrels homens del loch o alqueries lurs tantsolament quant als crims comeses en los dits lochs o alqueries o dins termes o limitations daquelles. Exceptats tots casess on hais loch pena de mort natural o civil cas de mutilatio de membre...»; se otorgaba asimismo la jurisdicción alfonsina a los titulares de «...lochs o alqueries on stan o staran tres casats de moros o mes quant als lochs e alqueries situats e situades dins los termens dels lochs reals o altres on nos havem mer imperi e set casats de moros o mes en los lochs e alqueries situats e situades dins termens de lochs daltres persones havents mer imperi: exceptats tot cases on haia loch pena de mort natural o civil e cas de mutilatio de membre... ${ }^{2}$. En suma, el fuero añadía al ejercicio de una jurisdicción civil plena, y preexistente, el de una baja criminal, relativa a todas las causas de las que no pudiesen seguirse las penas citadas o alguna otra asimismo grave. Según Pla Alberola ${ }^{3}$, ha de entenderse que, originaria-

\footnotetext{
Id.: «Les divisions territorials valencianes a les Observaciones de Cavanilles», Cuadernos de Geografía, 1997, núm. 62, pp. 303-322.

${ }^{2}$ Furs e ordinations fetes per los gloriosos reys de Aragó als regnícols del regne de valéncia. Lamberto Palmart, Valencia, 1482 (facsímil Univ. Valencia, 1977).

${ }^{3}$ Pla Alberola, P.: «La jurisdicción Alfonsina como aliciente para la recolonización del territorio», Rev. de Historia Moderna (Univ. de Alicante), 1993, núm. 12, pp. 79-87.
}

$$
-614-
$$


mente, la posesión previa de la jurisdicción civil constituía premisa indispensable para el logro de la alfosina, que se producía cuando se realizaba el «compliment de casats» requerido en cada uno de los tres supuestos mencionados. Con el transcurso del tiempo, convertidos los mudéjares en cristianos nuevos, y a la postre expulsados sus sucesores, el vecindario mínimo para la consecución de la jurisdicción alfonsina fue de 15 hogares habitados, desvaneciéndose el requisito de titularidad anterior de la jurisdicción civil. Así, pues, en la Edad Moderna la creación de un señorío alfonsino suponía para su dueño la obtención simultánea de la jurisdicción civil plena y de la criminal baja o limitada.

Extinguida legalmente la susodicha duplicidad foral en las Cortes de 1626, el fuero alfonsino no tuvo, sin embargo, dificultad alguna de supervivencia, transformado, a la vez, en incentivo de colonización interior y vía de promoción social. Propietarios de grandes fincas rústicas, ansiosos de preeminencia y con la meta del título nobiliario, encontraron en la referida norma una excelente plataforma de partida para satisfacer esas ambiciones, tan consustanciales con la época. Y no sólo fueron personas físicas, también comunidades religiosas y algún cabildo catedralicio. Más aún, se produjeron innovadoras y sorprendentes utilizaciones del fuero, al hacer beneficiarias del mismo a comunidades locales; en efecto, desde 1574 sirvió para la segregación de populosos lugares, a los que se concedió la categoría de universitat, inmediatamente inferior a la de villa, confiriéndoles la jurisdicción alfonsina, mientras la suprema quedaba reservada a la capital de término matriz. De este modo, y a los efectos que ahora interesan, el fuero alfonsino auspició la fundación de nuevos lugares y facilitó la egresión de otros, de la misma forma que había permitido el afianzamiento de antiguos señoríos de atribuciones jurisdiccionales poco claras o cuestionadas.

Tras la abolición general de los fueros valencianos en 1707, el denominado alfonsino fue reinstaurado, el año 1772, por Carlos III como instrumento de colonización y reforma agraria en el reino de Valencia. Más aún, el Consejo de Castilla propuso, y la Sociedad Económica de Amigos del País de Valencia alentó, su extensión al resto de España. Además de dichos objetivos existía, en íntima relación con ambos, otro motivo de singular trascendencia, consistente en la aspiración de integrar a dueños de amplias superficies yermas o insuficientemente cultivadas en el proyecto reformista; se trataba, en definitiva, que éste no se redujese a los grandes empeños colonizadores estatales (Sierra Morena, 
Nuevas Poblaciones de Andalucía, Campo de Lorca) y a meras desamortizaciones de propios y comunales, sino que incorporasee, en la mayor medida posible, las haciendas y capitales de grandes propietarios deseosos de acceder, a través de la indicada vía, a la condición de señores de vasallos, como paso previo, a la consecución de título nobiliario.

La vigencia excepcionalmente larga del Fuero de 1329 ha dejado, entre otras huellas, una amplia y profunda en el mapa municipal valenciano. Tras un activo proceso de desaparición, por agregación o fusión, durante los dos últimos siglos de gran número de términos con raigambre alfonsina, éstos, son aún más de un centenar en la Comunidad Valenciana.

\section{Rasgos peculiares de la jurisdicción alfonsina}

Una serie de limitaciones distinguían esta jurisdicción civil plena y criminal baja llamada alfonsina de la suprema o baronal. A la primera escapaban, como se ha dicho, delitos de los que pudieran seguirse pena de muerte, destierro, mutilación o castigo corporal por encima de cien azotes; tampoco figuraban entre sus cometidos los de someter a interrogatorio y tormento a los acusados. En cambio, los titulares de la jurisdicción alfonsina percibían la mitad de las penas pecuniarias en los procesos criminales antedichos, y, desde luego, conocían y sancionaban los delitos criminales no exceptuados, recibiendo íntegramente las caloñas y multas correspondientes. No es preciso encarecer que la exclusión de la pena capital resultaba más una cuestión de competencia formal que de alcance real, puesto que cien azotes, y aún bastantes menos, propinados por mano diestra bastaban para ocasionar la muerte; sólo así se entiende la alternativa según la cual, «si per los dits açots de cent a ensus o a enius lo moro dira que vol esser catiu», se establecía su venta en pública subasta y el reparto por igual del precio entre los titulares de las jurisdicciones baronal y alfonsina. Si algún vasallo incurría en pena de confiscación, sus bienes se consideraban aplicados con anterioridad a la señoría directa, de manera que se consolidasen en sus manos ambos dominios.

Controvertidos fueron algunos aspectos tocantes a la administración local. Bas y Galcerán señala que «si ergo Domini oppidorum solum ha- 
beant illud mixtum imperium, mediocrem potestatem, iurisdictionem Alfonsinam, non poteruunt legitime universitatis bona alienari cum illorum licentia, sed Regia debet interponi, hoc modo vera est DD. sententia supratradita, impermitens alienationem bonorum universitatis cum licentia domini particularis» ${ }^{4}$. Cuestión muy debatida fue, en los siglos XVI y XVII, si los poseedores de la jurisdicción alfonsina podían o no exigir cuentas a los administradores de propios; surgieron doctrinas encontradas y hasta se produjeron sentencias y pragmáticas contrapuestas.

A la competencia de aquéllos excedía la facultad de conceder licencia para la imposición de contribuciones o sisas, reservada a la jurisdicción baronal. Tampoco podían legalmente los señores alfonsinos exigir a sus vasallos trabajos, servicios, hospedajes ni cabalgaduras; aunque la realidad resultó, más de una vez, bien distinta. En cambio, asistía a los titulares de la jurisdicción alfonsina el derecho de comparecer por su propio interés, personalmente, ante los de mero imperio cuando, en el marco competencial de éstos, se maltratase a vasallos de ambos. Disfrutaban los señores alfonsinos de derechos exclusivos, privativos y prohibitivos, reducidos habitualmente, por lo exiguo del vecindario, a molino, almazara, horno y pastos, menos usual era el de abasto de víveros por la razón indicada.

Pla Alberola ha dedicado páginas muy jugosas al examen del perfil de la jurisdicción alfonsina, su significación, nivel y contenido, ámbito de aplicación y condiciones de adquisición ${ }^{5}$. No parece discutible el carácter original de fuero con que se otorgó el precepto, y, por tanto, su antigua vigencia en todas las áreas del reino sometidas a Fuero de Valencia, tanto de realengo como de señorío. La naturaleza y contenido primigenios de la jurisdicción alfonsina distan mucho de ser completa novedad, tal y como evidencia un análisis de derecho comparado con otros estados de la Corona de Aragón, las Partidas y algún ejemplo francés; dicho estudio revela la existencia de jurisdicciones coetáneas de notorias semejanzas con la que nos ocupa. Reviste, empero, la ju-

${ }^{4}$ Bas et Galceran, N.: Theatrum iurisprudentiae Forensis Valentinae, romanorum Iuri Mirifige Acomodatae, Pars prima, t. I, Valentia, Ex Typ. Laurentii Mesnier, 1960, p. 222 .

${ }^{5}$ Pla Alberola, P.: Conflictos jurisdiccionales en un gran señorío valenciano. El condado de Cocentaina ante la consolidación del absolutismo (tesis doctora inédita). Dpto. de Historia Moderna, Univ. de Alicante, 1985. 
risdicción alfonsina particularidades destacables, que invitan a cuestionar su identificación con otras denominaciones. Entre aquéllas, son de notar su honda raigambre valenciana, procedimiento de obtención y el propio sistema para la fijación de competencias en materia criminal.

Resulta obvio que el contenido del fuero alfonsino refleja la dualidad esencial que caracteriza a la sociedad valenciana de la época, integrada por cristianos y mudéjares; recordemos como la norma propicia, con una exigencia de vecindario muy desigual, la proliferación de lugares y lugarejos alfonsinos en áreas de población musulmana, concentrada primordialmente en dominios señoriales. Es de resaltar también la relevancia atribuida a la pena de látigo, usual entre los moros, infrecuente para los cristianos; y, junto a ello, la posibilidad expresa de que los primeros, para evitar un castigo grave de ese tipo, que podría tener fatales consecuencias, opten por la esclavitud.

Con todo, la singularidad de la rúbrica De iuredictio atorgada a aquells qui no han mer imperi radica en que la jurisdicción alfonsina se conseguía, en época foral, de forma automática, sin necesidad de título expreso, una vez producido el «compliment de casats». El automatismo subsistió, aun cuando se complicasen los trámites, tras el restablecimiento del fuero por Real Provisión de 16 de mayo de 1772; una hoja de propaganda para alentar la creación de lugares hacía constar que «...el Fuero sólo pide dos circunstancias, la primera construir las quince Casas: La segunda poblarlas de Christianos Casados. Purificadas las condiciones, por el ministerio de la Ley, se adquiere la Jurisdicción perpetuamente. El conocimiento de estas causas es privativo del Real Acuerdo y conoce instructivamente mandando poner en Posesión al que ha cumplido las dos condiciones. Aunque después, estas causas se hagan contenciosas, siempre obtiene sentencia favorable el fundador del Pueblo: porque la declaración de haber cumplido el contrato, es irrevocable, porque la Ley le favorece... Por estos motivos siempre el Real Acuerdo, conoce, y posesiona a los Fundadores de los Lugares, por tratarse de una Ley hecha en Cortes; de un contrato mutuo, citroque obligatorio, de un contrato oneroso; de un contrato de buena fée, fiado en la Palabra Real...» ${ }^{6}$.

Otro aspecto peculiar consiste en que la limitación del mero imperio o jurisdicción criminal se establece en función de las penas imponibles

${ }^{6}$ Noticia del Fuero Alphonsino. 
y no directamente por el tipo de delito, quedando así abierta la posibilidad de que la agravación de aquéllas sustrajera alguno de ellos a la competencia de los titulares de la jurisdicción alfonsina.

Originariamente el Fuero de 1329 abrió para los titulares de señoríos de jurisdicción civil la posibilidad de añadir a ésta un mero imperio restringido, siempre que recibiesen los Furs y reuniesen el vecindario preciso; se trataba, en efecto, de extender aquéllos a costa de afianzar e incrementar unas atribuciones jurisdiccionales reconocidas o controvertidas. En la Edad Moderna, y particularmente tras el extrañamiento de los moriscos y el término de la duplicidad foral, con la única y exclusiva vigencia de los Furs, dispuesta por las Cortes de 1626, el fuero alfonsino, que hace ahora plenamente presente su virtualidad repobladora, sirve a la fundación de nuevos lugares; de manera que, en este nuevo contexto, el dueño de una heredad con quince casas habitadas obtiene la jurisdicción alfonsina, es decir, logra, ex novo y a un tiempo, la jurisdicción civil plena y una criminal limitada. Así, pues, en modo alguno cabe la sinonimia, tan prodigada, entre jurisdicción alfonsina y mixto imperio, que, peca, a todas luces, por defecto, ya que la primera incluye también, junto al segundo, un mero imperio acotado, como se ha dicho, por la gravedad de la pena; de ahí que Francisco Jerónimo de León, en 1646, afirme que "Alphonsus rex concessit certus gradus meri imperi sive jurisdictionem alphonsinam dominis oppidorum consentientibus foris» y precisa: «Hic igitur rex in curiis celebratis Valentiae anno 1328 (sic) concessit praelatis, richis hominibus, militibus et civibus habentibus oppida seu loca in regno Valentiae absque mero imperio, qui consentirent foris in dictis curiis factis tres ultimos gradus meri imperi... Nimirum merum imperium parvum, minus et minimum et omne mixtum imperium ${ }^{7}$. Pla Alberola ${ }^{8}$, que ha investigado detenida y agudamente esta cuestión, señala el precedente de Guillem Jaffer, quien escribió, antes de la promulgación del fuero alfonsino, acerca de «qual coses son aquelles e compreses sots aquestes paraules de mer imperi e tota jurisdicció criminal e quals coses son aquelles compreses sots jurisdicció civil», diferenciando un mero imperio para «grans feyts» y otro «puxe jusà», y significativamente la pena de exposición en la picota — que será a partir de 1329 el símbolo de la jurisdicción alfon-

${ }^{7}$ Decisionum Don Francisci Hieronymi de Leon. Valentia Ex Prado Sylvestri, in vico scapharum, 1646, lib. III, dec. X, 4-5.

${ }^{8}$ Pla Alberola, op. cit., 3 , p. 81 . 
sina, como la horca lo era de la suprema o baronal-correspondia a ese «mer puix jusà». Recordemos también, en idéntico sentido, que los renglones iniciales del fuero de 1329 establecen, inequívocamente, que "prelats, persones ecclesiastiques, richs homens, cavallers, persones generoses, ciutadans e homens de viles qui no han mer imperi haien iuredictio civil e criminal e exercici conexença e determinatio daquella...»Por tanto, resulta sorprendente, salvo que se admita la intención de reducir el alcance de la jurisdicción alfonsina, la identificación por una mayoría de tratadistas e inumerables documentos de aquélla con el mixto imperio, ignorando su participación, con las limitaciones indicadas, en el mero. Y éste era el planteamiento existente cuando, tras la abolición de 1707, el fuero alfonsino, que se llama también en esta ocasión privilegio, fue reinstaurado por la Real Provisión de 16 de mayo de 1722. Sin embargo, curiosamete, unos años después aparece un testimonio implícito de que la jurisdicción alfonsina era algo más que mixto imperio; se trata de la real Cédula de 23 de diciembre de 1778 sobre $R e$ glas para la situación y construcción de los pueblos en el camino de Madrid por la provincia de Extremadura, cuyo artículo sexto disponía que «llegando a veinte vecinos, gozarán de la jurisdicción alfonsina para que se puedan defender de toda vexación» ${ }^{9}$, finalidad francamente difícil de conseguir si la jurisdicción otorgada fuese ajena al mero imperio y no tuviese parte en el mismo.

\section{Lugares y universidades alfonsinas anteriores a la expulsión de los moriscos}

Jurisdicción baronal, alfonsina, civil e ínfima se imbrican y superponen en los grandes estados nobiliarios del reino de Valencia que, poblados mayoritariamente por mudéjares primero y moriscos después, ocupaba en gran parte «aquel cuartel de nuestro reyno, que llamamos las Montañas por ser montañoso, y se extiende desde Castilla al mar, y de Xátiva a tierra de Alicante» ${ }^{10}$.

${ }^{9}$ Novísima Recopilación, Libro III, Título IV, Ley VI, «Reglas para la situación y construcción de los pueblos en el camino de Madrid por la provincia de Extremadura», 1778.

10 Escolano, G.: «Apuntes para el estudio de las rentas en el siglo Xvi. Los pequeños señoríos del Quartel de las Montañas», Jerónimo Zurita. Su época y su escuela (Congreso Nacional. Fundación «Institución Fernando el Católico», Diputación Provincial de Zaragoza). 
Ejemplos prototípicos constituian el condado de Cocentaina, ducado de Gandía y marquesado de Denia. La fragmentación señorial del condado de Cocentaina era considerable al producirse, en 1609, la expulsión de los moriscos. Estos habitaban en diecisiete localidades de muy diversa entidad, y ocho de ellas eran señoríos cuyos titulares habrían ejercido algún tipo de jurisdicción, si bien únicamente Benamer, Cela de Núñez y Fraga revestirían carácter de lugares alfonsinos; a la postre, adquiridos los otros dos por el conde, empeñado en la homogeneización jurisdiccional de su baronía, sólo perduraría como tal Cela de Núñez ${ }^{11}$. Más que mediado el siglo XvI, Martín de Viciana indica que «dentro de los límites del ducado de Gandía son los lugares de Piles, Palmera, Rafelsinen, Daymus, Benireda, Beniarjo y Pardines. De los quales (aunque son de particulares señores) el Duque tiene la jurisdicción en el crimen y sangre» ${ }^{12}$. Y vísperas del extrañamiento de los moriscos, señala Escolano, tras describir el condado de Oliva y el ducado de Gandía, «todos los sobredichos pueblos tienen los nombres arábigos, y están poblados de moriscos bautizados, como también algunos de los que se siguen, que están dentro de esta Conca y en su comarca; si bien tienen otros dueños. Estos son Potrias, Palma, Ador, Beniarjó y Pardines de los Moncadas, marqueses de Aytona. El Misera (o como pronuncian los moros, Mesera), es de los caballeros del apellido de Ros. Rotaba, de los Arnaus de Gandía... Y finalmente Alfahuir a una legua de Gandía, hacia la montaña... Ador y Palma hacen una baronía, con ciento y setenta casas entre los dos, y un castillo cerca de la montaña de la Zafor... El que nosotros llamamos Beniarjón, llamaron ellos Benizarjón, y es pueblo de cien casas...; Rótova tiene treinta casas: Alfahuir de los frailes de San Gerónimo de Cotalba, cuarenta» ${ }^{13}$. Pero a todos los estados nobiliarios ganaba en número de señoríos alfonsino el marquesado de Denia; tras dar cumplida relación de los mismos y de sus propietarios, afirmaba Viciana que «En todos estos diez y ocho Lugares, el marqués tiene la Suprema Jurisdicción en el crimen, y a los Señores de los Lugares, pertenecen

11 Pla Alberola, P.: «Apuntes para el estudio de las rentas señoriales en el siglo XVI. Los pequeños señoríos del Quartel de las Montañas», Jerónimo Zurita. Su época y su escuela (Congreso Nacional. Fundación «Institución Fernando el Católico», Diputación Provincial de Zaragoza).

12 Viciana, M. de: Crónica de la Ínclita y Coronada Ciudad de Valencia (reimpesión facsímil de la edición de 1564. Estudio preliminar e índices por Sebastián García Martínez, Valencia, 1972-1983), II, pp. 22-25.

13 Escolano, op. cit., col. 189-192. 
las rentas, aprovechamientos, y jurisdicción civil, y baxa, según el feudo de Valéncia» ${ }^{14}$. Más próxima a la toponimia actual y con referencia más precisa a las atribuciones jurisdiccionales queda la noticia de Escolano, según la cual: «El Marquesado de Denia... tuvo siempre debajo de su jurisdicción los pueblos siguientes: Miraflor, que es de don Jaime Perpiñán, con veinte y cinco casas, Setla y Mirarosa, de don Juan Uhuarte con sesenta... También es de la jurisdicción de Denia la villa de Ondara que es de los Cardonas, Marqueses de Guadalest... El conde de Cenarcas, vizconde de Chelva, es señor en este distrito por su madre Doña Leonor Ponce de Benicadim, Beniherbeig y de Benihomer... Benimelique, pueblo de cuarenta casas hoy lo ocupa el Fisco real por cierta condenación y sentencia dada contra don Pedro Franqueza su dueño. Tormos de un caballero llamado Juan Bautista Catalán, es de veinticinco casas. Ráfol de los Murs... tiene veinte y seis. Negrales, de los Pascuales, hidalgo de Oliva veinte. Pedreguer y Matoses, del conde de Anna..., más de ciento. Gata, de don Pedro Hijar, cincuenta. Benicadim de los Estevanes doce. Pamies de los Vivas veinte. Y Sagra y Zenete, pueblos de la Encomienda de Santiago tienen cuarenta casas...; del cual y de los demás tiene el Marqués la suprema jurisdicción, y los señores solamente la que llamamos Alfonsina» ${ }^{15}$.

Entre los grandes términos generales de realengo, ninguno ofrecía una concentración de lugares alfonsinos equiparabe a la de Játiva; aunque atribuyendo a éstos una jurisdicción civil que ya no era tal, sino alfonsina, proporciona cumplida referencia Viciana. Tras citar los sesenta y dos pueblos incluidos en el término general de Játiva, indicando, en su caso, a quién pertenecía cada señorío, continúa en los renglones siguientes: «Todos estos pueblos se incluyen dentro los términos generales de Xativa, que son hasta tres leguas poco más o menos de través y largo... En estos pueblos de los términos generales la ciudad de Xativa tiene señorío diferenciado, es a saber: En Castellón, Enova, Beniganim, Montaverner, Ollería, Vint y Cinch y Losa toda jurisdicción mero y mixto imperio; la baronía de Canals es propia de la ciudad con toda jurisdicción y es regida por los jurados de la ciudad... La torre de Canals que es de la mesma baronía compró la ciudad de Xativa de don Rodrigo de Borja... En todos los otros pueblos la jurisdicción en el crimen per-

14 Viciana,op. cit., II, PP. 144-148.
15 Escolano, op. cit., col. 142-143. 
tenece al justicia de la ciudad. Y en los cargos de sisas y en las fábricas y conservaciones de muros, valles o fossos de la ciudad todos los pueblos contribuyen en cierta cantidad repartida entre ellos por tassa. Y en los demás de estos pueblos los cavalleros que los posseen son señores dellos, y cogen las rentas, y resciben otros aprovechamientos, y usan de jurisdicción entre sus vasallos en las causas ceviles según disposición de fueros del reyno» ${ }^{16}$. Ejemplo de entidad menor era el de Penáguila, en cuyo «término ay estos lugares: Benifallim de Pedro Castello de Alcoy, Benilloba del conde de Aranda, Benazau de Pujasons de Cocentayna, Ares del comendador Bosch, Alcoleja con sus lugares de Miguel Fenollat; y en todo el termino y lugares susodichos la jurisdicción en el crimen es de Penáguila, y todos ellos contribuyen en pechos y fabricas de muros...» ${ }^{17}$.

Paradigmas notorios constituían asimismo, en los extremos meridional y septentrional del reino de Valencia, respectivamente, los términos generales de Orihuela y Morella. El primero, cuyo número de lugares alfonsinos se acrecentaría considerablemente en el transcurso de los siglos XVII y XVIII, incluía ya varios, sin que faltase alguna baronía, mediado el quinientos; por entonces, correspondían a aquél, además de la ciudad, los pueblos siguientes: «... Callosa con su castillo, Catral, Almoradí y la fuerte villa de Guardamar que son quatro aldeas de la ciudad. Rodova de don Luys Sanctangel, Cox con su castillo de mossen Juan Royz, la Granja de don Juan de Rocamora, Albatera de don Enrique de Rocafull, Benejusser de mossen Francisco Martín. La Daya y Rojales de mossen Luys Masquefa...» ${ }^{18}$. Por su parte, el término general de Morella comprendía esta villa y una serie de núcleos, que eran los siguientes: «...El lugar de la Todolella que possehe mossen Francisco Joan Ciurana cavallero... En este lugar conosce de causas criminales el justicia de Morella. El lugar de Villore, que posee el mesmo Ciurana... En el crimen conosce el justicia de Morella. El lugar de Erbesjusan, possee mossen Luys Valls cavallero... El lugar de Ortells que possee mossen Joan de Brusca cavallero, en el crimen conosce el justicia de Morella. El castillo y lugar de Olocau es haldea de Morella... El lugar de Cati... haldea, en el que el justicia mayor de Morella pone un lugartiniente para las causas ceviles. El lugar del Forcall. El lugar de Cinch torres. El lugar de Portell. El

16 Viciana, op. cit., II, pp. 129-131.

17 Viciana, op. cit., II, p. 94.

18 Viciana, op. cit., II, pp. 156-158. 
lugar de Castellfort. El lugar de Villafranca. El lugar de Vallbona. Estos antedichos seys lugares son haldeas de Morella como los es Catí. El lugar de Sarañana. El lugar de la Mata. El lugar de Chiva. El lugar de Palanques. Estos antedichos quatro lugares son havidos por calles de Morella. El monasterio de Benifaça y sus lugares que son la Puebla, Castell de cabras, Ballestar, y el Boxar, tiene el justicia de Morella la jurisdición en el crimen...» ${ }^{19}$; un conflicto plurisecular, a propósito del ejercicio de la jurisdiccion alfonsina, enfrentó a los abades de Nuestra Señora de Benifasá con la villa de Morella ${ }^{20}$.

Las crónicas de Viciana (1563) y Escolano (1609) reflejan los resultados de la vigencia del fuero alfonsino durante un período que, respecto de la segunda, vísperas ya de la expulsión de los moriscos, abarca casi tres siglos desde su promulgación. Como denominador común, durante el otoño de la Edad Media y los albores de la Moderna la norma de 1329 contribuyó, a tenor de su objetivo originario, a la unificación foral, consumada en las Cortes de 1626; sin embargo, esta prolongada etapa dista de ser uniforme, ya que engloba coyunturas diferentes, donde la utilización del fuero tampoco es idéntica. Hasta mediados del siglo xv los señoríos alfonsinos, salvo excepciones, no son lugares de nueva planta, sino fruto de la pervivencia del antiguo hábitat musulmán, de sus alquerías y rafales, afianzados, eso sí, por dicha disposición. Es de resaltar que la conversión en señoríos alfonsinos de pequeñas entidades de población mudéjar encontraba la facilidad adicional de la menor exigencia de vecindario. A tenor de todo ello, parece que podría concluirse, sin excesivo riesgo, que en esta primera fase el fuero alfonsino pudo servir, simultáneamente, a la unificación foral del reino, consolidación y policía de pequeños núcleos de población, y bastante menos a la fundacion de otros núcleos. A explicar estas consecuencias contribuyen la permanencia de un contingente mahomeano, y luego morisco, muy numeroso, el reparto espacial y jurisdiccional de estos efectivos demográficos, la estructura del hábitat heredado y hasta la distinción básica que hace el fuero alfonsino entre casats mudéjares y cristianos.

19 Viciana, op. cit., II, p. 156.

${ }^{20}$ Castell de Planell, J.: Por la villa de Morella con el reverendo abad y convento de Nuestra Señora de Benifasá sobre la jurisdicción ínfima criminal llamada alfonsina que dicho abad pretende en los lugares de su tenencia, sitos en los términos generales de la villa de Morella. Valencia, Imp. De Jayme de Bordázar, 1692. 
Supone Pla Alberola ${ }^{21}$, no sin fundamento, que la cifra inicial de señoríos alfonsino se redujo de manera considerable en los cien años siguientes, por diversas causas. Todo parece indicar que muchos señores que reunían los requisitos precisos para el logro de la jurisdicción alfonsina, al renunciar al Fuero de Aragón y jurar la observancia de los Furs, fueron premiados con el otorgamiento de la baronal. Está asimismo documentada una larga serie de concesiones de dicha jurisdicción suprema a titulares de la alfonsina mediante la fórmula del nombramiento como llochtinent del portantveus de general governador, es decir, gubernatorio nomine, in officium, pero con clara y generalizada tendencia a la perpetuación. Y, por último, no faltan casos de señoríos alfonsino que dejaron de serlo cuando fueron adquiridos por la persona física o jurídica que ostentaba la jurisdicción suprema, es decir, el barón y, en caso de realengo, la villa o ciudad que encabezaba el término general. Una coyuntura diferente arranca de mediados del cuatrocientos, a favor del inicio de la recuperación demográfica y económica, y cubre la centuria siguiente; a los efectos que ahora interesan, supondrá la aparición de nuevos señoríos alfonsino mediante el acrecentamiento, por sus propietarios o compradores, de pequeñas entidades de población o la transformación en lugares, por medio del asentamiento de pobladores y el subsiguiente amojonamiento de extensas heredades.

Por otra parte, es de destacar que el fuero de 1329 puso las bases de la fragmentación de términos generales no sólo a través de lugares alfonsinos de señorío secular, eclesiástico o de abadengo, sino también por la transformación en universidades de lugares enteramente dependientes de villas o ciudades reales. Y es que el fuero facilitó la segregación de núcleos a los que su incremento demográfico, con el avecindamiento, sobre todo, de cristianos viejos, permitió, mediante la entrega de gruesas sumas a un erario exhausto, adquirir el rango de universidades, superior al de lugar e inferior al de villa; para mitigar las tensiones inherentes a la separación y obviar la reticencia, cuando no franca oposición, de la villa o ciudad cabecera del término general, se concedió a dichas universidades la jurisdicción alfonsina, mientras que aquéllas mantuvieron la suprema y, en definitiva, la preeminencia. El ejemplo de Algemesí ${ }^{22}$, segregada de Alcira en 1574, cundió por doquier entre nú-

${ }^{21}$ Pla Alberola, op. cit., 3, pp. 87-88.

22 Ballester Broceta, B.: Historia de la Villa de Algemesí, según manuscrito de... (1873), con notas de su bisnieto don Juan Segura de Lago. Algemesí, 1958, pp. 109-120. 
cleos que se hallaban en parecidas circunstancias; tales fueron, por ejemplo, los casos de Callosa (1579), en tiempos aldea de Orihuela, Muchamiel (1580) y San Juan-Benimagrell (1593), sometidos a partir de entonces tan sólo a la jurisdicción suprema de Alicante, Olleria (1583), sustraída a Játiva, Carcagente (1576) y Guadasuar (1581), antiguos lugares, como Algemesí, de la contribución de la villa de Alcira, y procesos similares fueron los de Ibi (1578) y La Yesa (1583), enteramente dependientes hasta entonces de las villas de Jijona y Alpuente respectivamente; más tardías son las transformaciones en universidades de Bañeres (1628), a expensas de Onteniente, villa de la que ya se había disociado, con el alcance indicado, Agullent en 1585, «...por haber sido su acrecentamiento tanto, que se halla con trescientas casas de cristianos: por lo cual le dió el rey Felipe segundo exención y titulo de universidad: que como tenemos dicho, es en este reino punto menos de villa, y más que lugar» (Escolano, II, 555), y de Alfafara (1632), esta última en el término general de Bocairente. Según Bernabé Gil ${ }^{23}$, la expansión económica y el crecimiento poblacional del Quinientos explicaría, en parte, la notoria multiplicación de universidades de realengo entre 1574 y 1593 , período que muy aproximadamente finaliza con el cambio de coyuntura.

\section{Señoríos alfonsinos del siglo XVII}

Dichas universidades, habitadas en muy alta proporción por cristianos viejos, no sufrieron las consecuencias de la expulsión de 1609 en grado parecido al de numerosos señoríos alfonsino con vecindario exclusiva o mayoritariamente morisco. Muchos de ellos se convirtieron en despoblados a causa del extrañamiento, a través de un proceso de marcado carácter selectivo y en función, sobre todo, de las posibilidades de repoblación. Perduraron, en líneas generales, los señoríos alfonsinos de mayor entidad y los que, enclavados en términos de realengo, atrajeron nuevos pobladores. A pesar de la doctrina contraria sostenida por Mateu y otros tratadistas, adoptada finalmente por las Cortes de 1626,

${ }^{23}$ Bernabé Gil, D.: «Universidades y villas. Notas sobre el proceso de segregación municipal en el Realengo valenciano (siglos XVI y XVII)», Rev. Historia Moderna, 19861987, núms. 6-7, pp. 11-38.

$$
-626-
$$


hay pruebas fidedignas, como las cartas pueblas de Negrals y Adsubia ${ }^{24}$, de que los antiguos señoríos alfonsinos con menos de quince nuevos pobladores, mínimo ahora indispensable y único, perdieron su condición de tales por más o menos tiempo, y, en última instancia, hasta las referidas Cortes.

La expulsión de los moriscos, en suma, no sólo produjo, como se ha dicho, la desaparición de multitud de señoríos alfonsinos y otros de baja jurisdicción, sino un largo hiato en la aparición de nuevos, con alguna excepción puntual y la salvedad notoria del Bajo Segura ${ }^{25}$. En la primera mitad del siglo XVII los señoríos alfonsinos atravesaron por momentos difíciles. Aparte de los señores que vieron dificultado o negado el ejercicio de la jurisdicción alfonsina al quedar sus lugares despoblados o con menos de quince vecinos, hubo otros que, tras haber defendido sus derechos frente a los titulares de la jurisdicción suprema, a menudo durante siglos, acabaron por desistir, enajenando sus posesiones en favor de aquéllos.

También algunos señoríos de jurisdicción alfonsina dejaron de serlo al obtener sus titulares la jurisdicción suprema gubernatorio nomine, posibilidad que quedaba reservada a quienes tuviesen señoríos radicados en términos de realengo. Sin salir del extenso distrito de Orihuela, la consiguieron los señores de Benejúzar (1628), Cox (1629), Rafal (1636) y La Granja (1646). Los candidatos a la jurisdicción suprema gubernatorio nomine alegaban, casi siempre, que su ejercicio mejoraría la administración de justicia y que «d'esta manera no sols se administrarà ab mes egualtat justícia, pèro encara cessaran diversos plets, causes e inquietuts que cascun dia tenen ab los senyors de la suprema jurisdicció». Sin embargo, las capitales de los términos afectados por tales egresiones se oponían, invariablemente, a dichas concesiones.

Antes de 1626 el fuero alfonsino sirve ya, como se ha indicado, otros cometidos; entre ellos descuella, por su trascendencia, el que aúna estrechamente colonización de latifundios, fundación de lugares y transformación de sus dueños en señores de vasallos. Razones de orden económico, aunque estén bien presentes, no son siempre prioritarias,

${ }^{24}$ Gil Olcina, A.: «La propiedad de la tierra en los señoríos de jurisdicción alfonsina», Investigaciones Geográficas, 1983, núm. 1, pp. 10-11.

${ }^{25}$ Gil Olcina, A. y Canales Martínez, G.: Residuos de propiedad señorial en España. Perduración y ocaso en el Bajo Segura. Alicante, Inst. Juan-Albert, 1988, pp. 78-79.

$$
-627-
$$


casi siempre privan otras de promoción social y ascenso nobiliario. Estas cuestiones de preeminencia, habitualmente presentes en la erección de señoríos alfonsinos seculares, no son tampoco ajenas a las instituciones religiosas; el original y complicado trámite seguido por el Cabildo de la Catedral de Orihuela para crear Bigastro es incomprensible si se desconoce su rivalidad con el Colegio de Santo Domingo de la misma ciudad, que ejercía ya por entonces la jurisdicción alfonsina sobre Redován y Hondón de los Frailes ${ }^{26}$.

Del primer tercio del siglo XviI son los señoríos alfonsinos de Benejúzar, Benferri, Rafal y Jacarilla, todos ellos en el Bajo Segura, es decir, en tierras de realengo y con riego o posibilidad de transformación a partir de azudes del Segura. Mención especial merecen Benferri (1622) y Rafal (1636), lugares ambos de Don Jerónimo Rocamora, primer marqués de Rafal y, al decir, del Consejero Castellví, «caballero muy cualificado y de los más principales deste reyno y de grandísima hazienda, la mayor que ay en aquella parte de Orihuela» ${ }^{27}$. Un completo ensamblaje de racionalismo económico y anhelo nobiliario caracteriza estos señoríos, que deparan prestigio e ingresos adicionales, además de la revalorización de grandes posesiones rurales, cuya explotación tenía por premisa indispensable disponer de mano de obra en un contexto de vacío demográfico; la forma de contar con ella fue la fijación de vecinos mediante el establecmiento enfiteútico, sin perjuicio de que una porción importante de la heredad se reservase a la administración directa, arrendamiento a corto plazo o terraje.

Más de cincuenta años transcurren entre la creación de Rafal (1636) y la presencia de nuevos señoríos en el Bajo Segura, coincidiendo con la recuperación económica y demográfica del último cuarto de siglo; y esta coyuntura expansiva permitió la fundación de lugares alfonsinos. Formentera, Benijófar, Molíns y Bigastro son los poblados levantados de nueva planta por entonces en término de Orihuela, además del proyecto fracasado de crear otro en el Diezmatorio de Catral. La primera de estas iniciativas colonizadoras fue de Jaime Gallego, ciudadano vecino de Orihuela, capitán de infantería, quien compró en 1686 la «heredat» de Benijófar y el 6 de agosto de 1689 otorgó carta puebla en favor de 16 en-

${ }^{26}$ Bernabé Gil, D.: Tierra y Sociedad en el Bajo Segura (1700-1750). Alicante, Univ. de Alicante, 1982, pp. 221-231.

${ }^{27}$ Bernabé Gil, D.: «La formación de un patrimonio nobiliario en el seiscientos valenciano. El primer marqués de Rafal», Rev. Historia Moderna, 1986, núm. 5, pp. 11-66. 

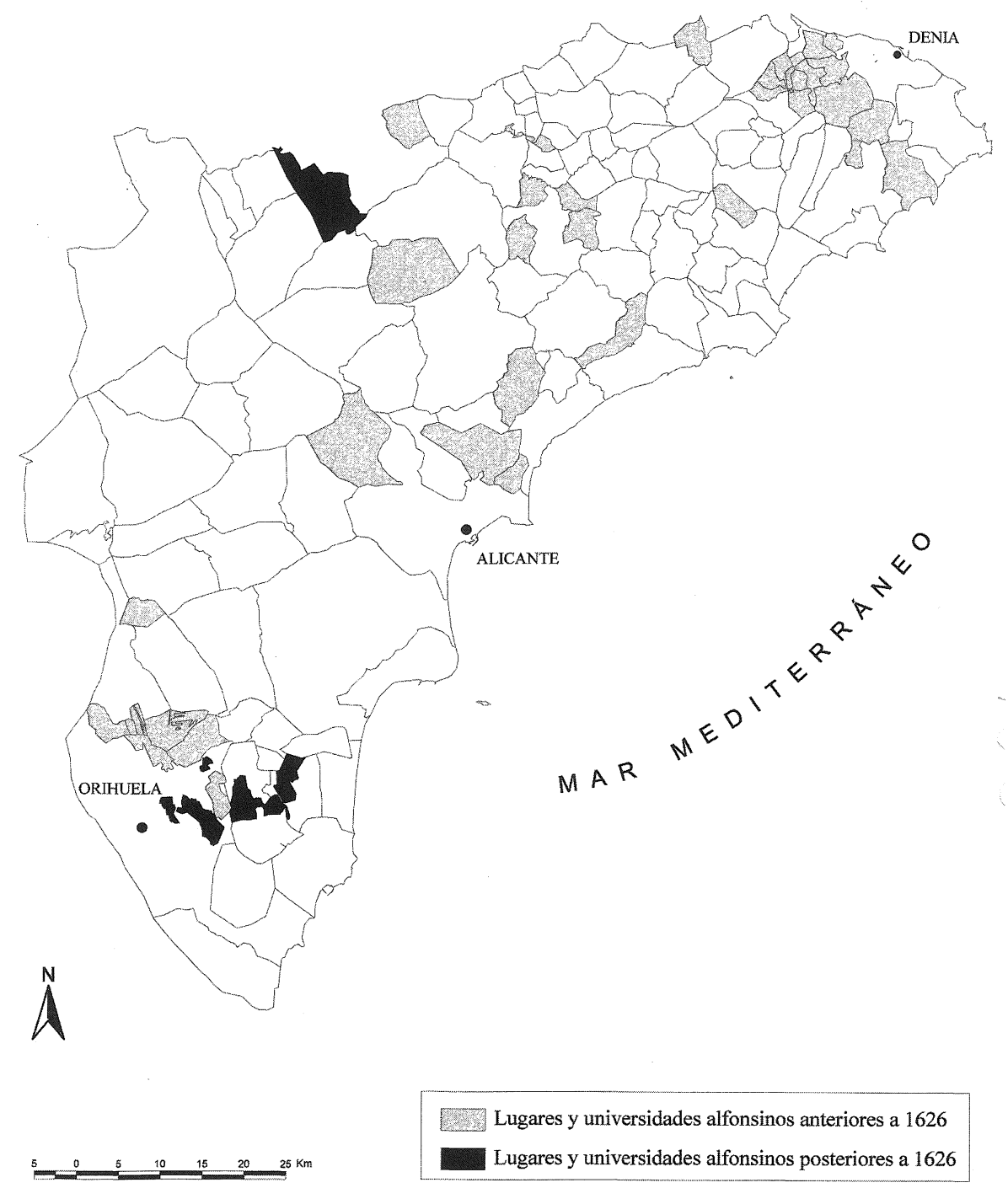

FIG. 1.-Provincia de Alicante. Lugares y universidades alfonsinos anteriores y posteriores a 1626. 
fiteutas, lo que hizo que poco después el baile de Alicante dictase sentencia admitiéndole el ejercicio de la jurisdicción alfonsina ${ }^{28}$. En 6 de mayo de 1691, el individuo de la clase de Generosos y Familiar del Santo Oficio de la Inquisición de Murcia, vecino de Orihuela, Don Ginés Juan Portillo y Soto, suscribía escritura de concordancia con 32 pobladores del lugar, de nombre todavía indeciso, que se proponía fundar en Catral, sobre una superficie de 136 hectáreas; pero el proyecto fue abandonado. También de 1691 es la carta puebla de Formentera, lugar de D. Carlos Pérez de Sarrió, primer gobernador de la ciudad y castillo de Játiva, y luego «lugarteniente de bayle general de la ziudad y reino de Valencia y del Consejo de V.M.», quien el 24 de diciembre de ese mismo año obtuvo sentencia a su favor sobre la jurisdicción alfonsina de dicho lugar ${ }^{29}$. Pocos años después, el día 23 de octubre de 1697, don Alfonso Rocamora y Molíns, caballero de Calatrava y vecino de Orihuela, firmó la escritura de concordia con los primeros pobladores del nuevo lugar de Molíns de Rocamora, dentro de la huerta y término de Orihuela ${ }^{30}$.

Unos meses antes de la carta puebla de Molíns, el Cabildo de la catedral de Orihuela, en sesión de 27 de julio de 1697, consideró la posibilidad de «hacer un lugar con base en las heredades de Alpartern y la Torre»; ambas fincas, al igual que otra tercera integrada en el coto redondo configurado, procedían de herencias en beneficio del alma. Después, con miras a ampliar la superficie disponible, que definitivamente fue la del actual municipio $\left(4,01 \mathrm{~km}^{2}\right)$, el cabildo adquirió, por vías de permuta y compra, otras haciendas lindantes con las anteriores. El preámbulo de la detallada carta puebla de cuarenta y dos capítulos, autorizada el 10 de octubre de 1701 y ratificada, con algunas variaciones, el 2 de junio de 1715, invocaba el fuero alfonsino para fundar un nuevo señorío con el histórico nombre de Bigastro, topónimo que acabó por prevalecer sobre el popular de Lugar Nuevo de los Canónigos ${ }^{31}$.

En estas condiciones, convertida la vega Baja del Segura en un auténtico vivero de señoríos alfonsinos, se produjo la insólita iniciativa del

\footnotetext{
${ }^{28}$ Bernabé Gil, D.: «Sobre el origen territorial en los señoríos valencianos de colonización alfonsina», Señorío y feudalismo en la Península Ibérica (siglos XII-XIX). Zaragoza, 1989.

${ }^{29}$ Bernabé Gil, D.: op. cit., 28

${ }^{30}$ Bernabé Gil, D.: Tierra y Sociedad en el Bajo Segura (1700-1750). Alicante, 1982, pp. 206-216.

${ }^{31}$ Canales Martínez, G. y Martínez García, I.: El señorío eclesiástico de Bigastro (siglos XVIII-XIX). Alicante, Inst. de Cultura Juan Gil-Albert, 1994, 304 pp.
}

$$
-630-
$$


concejo de Orihuela, en 1699, de crear en Torrevieja, paraje del propio término de dicha ciudad, un señorío alfonsino de titularidad municipal, para disponer de puerto propio; el planteamiento no prosperó por la cerrada oposición de Alicante, pero constituye, sin duda, ejemplo arquetípico de la lectura interesada y permisiva que, a fines del seiscientos, se hacía de la significación y alcance del fuero Otorgam de $1329^{32}$.

Añadamos, por otra parte, que de los señoríos finiseculares citados, cuyos titulares pretendieron beneficiarse de la expansión demográfica a través de cartas pueblas casi siempre muy exigentes, aunque también es preciso no olvidar que el terrazgo establecido o parte de él era regadío, no pudieron consolidarse hasta después del conflicto sucesorio, que traería aparejada la supresión de fueros.

\section{La jurisdicción alfonsina ante la supresión del derecho foral}

El referido movimiento recolonizador del último cuarto del siglo XVII quedó en suspenso con el estallido de la Guerra de Sucesión y la abolición de los Furs por el Decreto de 29 de junio de 1707. Sin olvidar que las pérdidas demográficas y los desórdenes de la contienda pudieron colocar a algunos señoríos alfonsinos en una situación crítica, con el agravante de la supresión de los fueros, el principal problema, a los efectos que nos ocupan, fue la propia supervivenca de la jurisdicción alfonsina.

El informe de Luis Curiel, fiscal del Consejo de Castilla, afirmó que las jurisdicciones alfonsinas «estaban revocadas e incorporadas a la Corona en virtud de la ley general en que se han derogado los Fueros de aquel reino». Sin embargo, una consulta al Consejo de Castilla de 10 de septiembre de 1708 motivó una resolución de dicho órgano, al parecer decisivamente influida por el confesor real, el jesuita Pierre Robinet, con fecha 5 de noviembre siguiente, que discrepaba del dictamen de la fiscalía en los términos siguientes; «...lo primero, porque en la abolición de afueros no puede estar comprehendido el fuero del Rey Don Alonso por el tiempo antecedente a la promulgación de la ley, ú decreto de la de-

${ }^{32}$ Bernabé Gil, D.: Elites de poder y administración municipal en una ciudad valenciana: Orihuela en la época foral moderna. Tesis doctoral, Dpto. de Historia Moderna, Alicante, 1988, p. 799. 
rogaración de fueros, ni causar perjuicio a los que en virtud del referido fuero, y cumpliendo con sus condiciones, adquieren el derecho de la jurisdicción por ley; y lo segundo, porque estas jurisdicciones Alfonsinas que tuvieron su origen en el fuero setenta y ocho, fueron adquiridos en fuerza de un contrato oneroso celebrado entre los Prelados y Ricos-hombres de aquel Reyno y el Rey Don Alfonso, concediéndoles éste la jurisdicción de todos los lugares que fundasen de quince vecinos, habiendo en aquella buena fe y promesa gastado aquellos naturales sus caudales en fundaciones de lugares, no se les puede quitar la jurisdicción, aunque después por la ley general se hayan revocado los fueros, por razón de haber sido adquirida en fuerza del referido contrato oneroso; y esta ley sólo podrá tener esos efectos en adelante en las fundaciones que de nuevo se hicieron después del decreto derogatorio de los referidos fueros» ${ }^{33}$. Por tanto, la resolución salvaguardó a los señoríos de jurisdicción alfonsina, pero no la vigencia del fuero de 1329, cuya derogación, sin efectos retroactivos, reconocía plenamente.

Sin embargo, pronto adquirió fuerza una corriente de opinión favorable al restablecimiento del referido fuero, cuyo valedor principal fue Melchor Rafael de Macanaz, que conoció muy de cerca los señoríos alfonsinos durante su actuacion como Juez de Confiscaciones y Comisionado para la reedificación de San Felipe (Játiva), en cuya comarca aquéllos eran, como se ha indicado, numerosos. Tras encarecer sus ventajas, sugería Macanaz no sólo su restablecimiento en el reino de Valencia, sino la concesión a otros reinos de la monarquía con el argumento de que el incremento de población se conseguirá, entre otros medios, mediante el procedimiento «de que usó el rey D. Alfonso el primero (sic) de Aragón. El cual, por su privilegio especial, concedió a todos los que en sus tierras hiciesen quince casas y que estubiesen habitadas de extraños, hubiesen en ellos y sus términos el señorío y cierta jurisdicción cuyo privilegio se extendió después entre los Fueros de Valencia y llaman a ésta la jurisdicción alfonsina. Y usando de dicho privilegio se ve aquel reino el más poblado de toda España, pues hay innumerables pueblos pequeños y procuran sus dueños mantenerlos para conservar el señorío, jurisdicción y autoridad que el privilegio y fuero les conce-

${ }^{33}$ Novísima Recopilación, Libro III, Título III, Ley III. Resolución de 5 de noviembre de 1708, a consulta del Consejo de 10 de septiembre, sobre «Observancia de los fueros Alfonsinos en el Reyno de Valencia respectivos a la jurisdicción de los lugares que se fundaron de quince vecinos». 
den» ${ }^{34}$. En suma, Macanaz propuso «que por una pragmática se les concediese a los que en sus propias tierras fabricasen diez casas y las hiciesen tener con vecinos, sean del país o extranjero, el mismo privilegio de autoridad, señorío, jurisdicción y vasallaje que en el reino de Valencia se concedía a los que querían gozar del privilegio del Rey D. Alfonso» ${ }^{35}$.

Aunque este planteamiento no prosperó y transcurriría medio siglo largo hasta el restablecimiento del citado fuero, lo cierto es que los señoríos alfonsinos, merced al argumento de que procedían de un contrato oneroso, enfrentaron mejor que las baronías los pleitos de incorporación a la Corona. Es de notar asimismo que, a pesar de la fuerte expansión demográfica que, concluido el conflicto sucesorio, informa el lapso de tiempo hasta la reposición en 1772 del Fuero de 1329, no se funda ni un solo lugar alfonsino y, a mayor abundamiento, el único intento documentado se salda con denegación; ello es prueba elocuente de que no se le hacía, por entonces, excepción alguna, y, al igual que los restantes fueros, éste se hallaba y tenía por abolido.

\section{Restablecimiento del fuero alfonsino}

Tras el intento fallido de Don Ignacio Pérez de Sarrió, en 1757, para obtener dicha jurisdicción en tierras de su propiedas establecidas enfiteúticamente en la partida alicantina de Campello, la reposición del fuero alfonsino fue obra de Carlos III, en respuesta al Memorial elevado por los nobles alicantinos Don Antonio Pasqual y Molina, marqués de Peñacerrada, y Don Ignacio Pérez de Sarrió, dueño del lugar de Formentera. El contenido de la Real provisión de 16 de mayo de 1772 era del tenor siguiente: «... Que en veinte y nueve de junio de mil setecientos y siete, se sirvió el Padre de Nuestra Real Persona avolir los Fueros y Privilegios con que se governava dicho reyno, y declarar en veinte y nueve de julio siguiente, que su Real ánimo no era quitar los Privilegios a sus buenos Vasallos de cuya clase eran los suplicantes, y lo avían sido sus descendientes, y causantes, lo que justificarían en caso necesario; antes

${ }^{34}$ Biblioteca Universitaria de Valencia: Ms. 24, ff ${ }^{\mathrm{o}} 25 \mathrm{v}^{\mathrm{o}}-26 \mathrm{r}^{\mathrm{o}}$ (Kamen, H.: La Guerra de Sucesión en España, 1700-1715, Barcelona, 1974, p. 445).

${ }_{35}$ Pla Alberola, op. cit., 3 , p. 100. 
bien preciso les daría nuevas Cartas: Que esta gracia era la que avía hecho repartir las dilatadas Heredades entre muchos, para que se cultivasse mejor la tierra, haciéndola fructificar... Que los suplicantes, y otros, estavan en la duda, si la declaración del Glorioso Padre de N.R.P. a favor de los buenos vassallos, sería extensiva a los Lugares que de nuevo fundassen, como parecía serlo; pero como era menester cantidades de consideración para construir dichas quince Casas y poblarlas de otros tantos vecinos casados, nadie se atrevía a expender sus caudales sin que precediesse declaración de ella: Por lo cual suplicaron a N.R.P. se sirviese declarar estar vigente a favor de ellos dicho Privilegio Alfonsino en los lugares que de nuevo fundassen en sus haciendas y de sus mugeres... se acordó expedir esta nuestra Carta: Por la cual os mandamos, que siendoos presentada, hagais publicar, y dispongais se publiquen en esse reyno nuevamente la confirmación y subsistencia del Fuero del Señor rey Don Alfonso del año mil trescientos y veintiocho (sic), en que concedió a los Vasallos que formasen Lugares con quince Casas, que no tenían imperio, tuviessen el mixto, con las calidades y circunstancias que en el mismo Fuero se contienen, por los buenos efectos que produjo en ese Reyno...» ${ }^{36}$.

Los gobernantes ilustrados intentaron resolver el problema de la despoblación de españa, y para ello se instruyó en 1768 el Expediente General de Despoblados del Reino. Pero era ésta cuestión sumamente compleja, tanto por la diversidad de las causas que la habían producido como por la amplitud de los intereses involucrados, que dificultaban mucho la solución ${ }^{37}$. Y, aunque el procurador general del reino defendió en 1768 que, dado «que uno de los motivos de la decadencia de la agricultura era la despoblación de muchos lugares de señorío causados por los dueños territoriales», «se les debía obligar a la población de todos los despoblados, repartiendo a los pobladores tierras y pastos bajo una moderada pensión, con reconocimiento del directo dominio», los ministros de Carlos III no se atrevieron a ello, por lo que apenas quedaba otra salida que la esbozada en los «Pactos y condiciones generales que se fixan para las nuevas poblaciones que pueden formarse en las dehe-

${ }^{36}$ Real Provisión en que nuevamente se confirma la subsistencia del Fuero del Sr. Rey D. Alfonso del año mil trescientos veinte y ocho, concedido a los Vasallos que formasen lugares. En Madrid, a 16 de mayo de 1772 (publicada en Valencia, a 3 de junio de 1772).

${ }_{37}$ Pla Alberola, op. cit., 3, pp. 104-124. 
sas y despoblados de señorío, y otras de término redondo, que posehen varios señores, cabildos, comunidades y particulares de qüenta de los mismos propietarios». Así, pues, se trataba de lograr que los latifundistas, mediante incentivos varios, se identificasen con la política de colonización interior y asumiesen protagonismo de primer orden en su desarrollo.

En el contexto extremadamente favorable que, entre otros hechos, integran el Expediente General de despoblados del Reino de 1768, la impresión en 1771 del Memorial Ajustado de la Ley Agraria, las disposiciones sobre reparto de propios y comunales (1776-1770), las Nuevas Poblaciones de Sierra Morena y Camino de Andalucía (1767), la traída de los genoveses de Tabarca establecidos en la Isla Plana o de San Pablo (1769), el plan de repoblación de los despoblados de Salamanca (1769), al que siguió el de los del partido de Ciudad Rodrigo, la fundación de San Juan de las Águilas (Murcia), con el inicio del vasto empeño reformista en el Campo de Lorca, y presidiendo, además, el Consejo de Castilla Aranda y teniendo un peso decisivo en el mismo Campomanes, dicho órgano había de ser necesariamente favorable a la solicitud de los dos nobles alicantinos citados. Su planteamiento agrario entroncaba con la política del reformismo ilustrado, salvo la contrapartida que suponía el logro de la jurisdicción alfonsina, cuestión sobre la que volveremos después.

Siendo entonces Don José Moñino el fiscal del Consejo de Castilla encargado de los asuntos de la antigua Corona de Aragón desde 1769, es más que probable que el dictamen favorable sea suyo. Pero el Consejo de Castilla, posiblemente por influyo de Campomanes, fue aun más lejos en la consulta que elevó a Carlos III el 10 de marzo de 1772, proponiendo su extensión a todo el reino. Sin embargo, la resolución real de 10 de abril de 1772 fue más cauta y no llegó tan lejos, redactada en los términos siguientes: «Siendo tan útil la formación de lugares pequeños para la más fácil cultura de los campos y aumento de la población; he venido en mandar, conformándome con el dictamen del Consejo, que se publique de nuevo en el reyno de Valencia la confirmación y subsistencia del fuero otorgado por el Rey don Alfonso en las Cortes de 1328... Y por lo que toca a la extensión de dicho fuero, que me propone el Consejo para toda España, me consultaría el modo, término y circunstancias con que podrá convenir que yo conceda esta nueva gracia» ${ }^{38}$.

${ }^{38}$ Suplemento de la Novísima Recopilación, Libro III, Título III, Ley I. 
Publicada la Real Provisión de 16 de mayo de 1772, quedaba de nuevo abierta la vía para conseguir la jurisdicción alfonsina, aunque parece que quienes la pretendieron hubieron de seguir una serie de trámites, que no siempre culminaron con éxito. Tras la reposición del fuero alfonsino, la Sociedad Económica de Valencia hizo intensa propaganda en favor del mismo, para alentar la fundación de lugares y la extensión de aquél a otros reinos de España. Con esta finalidad es acorde la anónima Noticia del Fuero Alphonsino, que, luego de una sucinta referencia al origen y diacronía de la citada disposición, indica los requisitos y trámites correspondientes, sin que falte la argumentación encaminada a convencer de que la consecución de la jurisdicción alfonsina era segura en cuanto se cumpliesen las condiciones exigidas ${ }^{39}$. Sin embargo, en abierto contraste con el automatismo de la época foral, el logro de la jurisdicción alfonsina no fue en el último cuarto del siglo xvIII tan rápido y sencillo como pretenden algunos de sus partidarios, sino que podía requerir un largo y enojoso trámite; además del caso de Algorfa, otros ejemplos, como el de la Vallonga de Burgunyo, convencen de ello.

Silencios descalificadores y discrepancias en torno al restablecimiento del fuero alfonsino

Inexcusable resulta la valoración de la proximidad temporal entre la citada Real Provisión de 16 de mayo de 1772 y el Memorial Ajustado del Consejo de Castilla de 1776, mediante el cual la Corona propiciaba la labor de los Fiscales de los Reales Consejos y alentaba la apertura de un Expediente sobre la Ley General de Incorporaciones, favoreciendo así la intensificación de la corriente abolicionista, con multiplicación de pleitos antiseñoriales. Se planteó así un cierto contrasentido, que mereció la discrepancia de algunos ilustrados, como Cavanilles.

En efecto, cabría pensar en actitudes contradictorias de la Corona, que, por un lado, favorecía un creciente intervencionismo de sus funcionarios en el régimen señorial, a la búsqueda de la incorporación de jurisdicciones, y, de otro, con el restablecimiento del fuero alfonsino, favorecía la expansión de aquél. Este contrasentido, que formal y teóricamente es incuestionable, no lo es tanto si se consideran los hechos

${ }^{39}$ Noticias del Fuero Alphonsino. Cortesía de P. Pla Alberola. 
en su contexto real, y, además, se pondera, en ese mismo marco, al alcance de la jurisdiccion alfonsina. No parece aventurado suponer que ésta, probablemente muy desvaída, lejos de sus capacidad punitiva originaria, no representaba merma alguna de la autoridad real ni suplantación de su justicia, sino, en todo caso, una acción complementaria de policía rural de pequeños núcleos, que sintonizaba con la política de colonicación interior propugnada por los gobernantes de reformismo borbónico. En este aspecto, resulta harto significativo que el propio monarca autor de la reposición del fuero alfonsino desestimase las solicitudes de terratenientes que ofrecían la repoblación de sus dehesas salmantinas a cambio de ciertas exenciones tributarias y de la concesión del mero y mixto imperio ${ }^{40}$.

Subrayemos también que, en esta segunda etapa de vigencia del fuero alfonsino, la posibilidad de trocar la jurisdicción inherente al mismo por la suprema o baronal, que, durante la época foral se había conseguido mediante la perpetuación de concesiones in officium o por compra, fue nula; tras 1772, el fundador de un lugar alfonsino obtenía una jurisdicción definitivamente limitada. Con todo, no puede desconocerse que la fórmula del fuero alfonsino, tan ensalzada por gobernantes ilustrados y sociedades económicas como instrumento para el aumento de la población, rompimiento de tierras y fomento de las cosechas, era un anacronismo; atenuado, desde luego, pero sin liberarse, por entero, de dicha tacha.

Son lugares alfonsinos del último cuarto del siglo xvIII, además del intento fallido de la Vallonga de Burbunyo (Burguñó o el Poblet) en término de Alicante, Peñacerrada o Pueblo Nuevo en el de Muchamiel, La Sarga en Jijona, San Rafael en Alcoy, Santa María de Aguas Vivas en Carcagente, Venta de Emperador en Museros, Daya Vieja (1791) en el Bajo Segura y también en esta comarca, seccionando el municipio de Almoradí, Algorfa (1798), postrero de los señoríos alfonsinos.

Como ya se ha indicado, tras la reposición del fuero alfonsino, la Sociedad Económica de Amigos del País de Valencia fue entusiasta propagandista del mismo, y en el mismo año de 1772 hizo suyo el proyecto de V.I. Franco para, con el incentivo a los estabilientes del logro de la jurisdicción alfonsina, asentar 1.500 familias, al menos, mediante la crea-

${ }^{40}$ García Zarza, E.: Los despoblados-dehesas salmantinas en el siglo XVIII. Salamanca, 1978, pp. 104-105. 
ción de nuevas poblaciones en los términos de Elche, Quart, Chiva, Cheste, Buñol, Turís, Liria, Benicarló y Vinaroz, así como junto a la Acequia Real del Júcar ${ }^{41}$.

Con esa actitud de resuelto y reiterado apoyo al fuero alfonsino contrasta el llamativo y sospechoso olvido de Cavanilles, quien, en sus Observaciones sobre la Historia Natural, Geografía, Agricultura, Población y frutos del Reyno de Valencia ni tan siquiera lo menciona. Cuando es obvio que el humanista, habitualmente tan bien informado, no podía desconocer el restablecimiento del fuero ni tampoco el aireado proyecto de V.I. Franco. A mayor abundamiento, cuando en su referida obra, nombra Bigastro, añade que se llama «comúnmente lugar nuevo» o, al citar La Sarga, indica que es «aldea de 15 casas», cifra por entero alusiva, y significativa, al igual que lo es la falta de referencia a Pueblo Nuevo de San Rafael o la mención escueta de Daya Vieja, sin indicar su condición ni la de ninguno de los múltiples señoríos alfonsinos del Bajo Segura, marquesado de Denia, ducado de Gandía, comarca de Játiva o término de Morella.

El silencio es, sin duda, intencionado, $\mathrm{y}$, con toda probabilidad, descalificador. A Cavanilles, que repudia tácitamente el restablecimiento del fuero alfonsino, debió parecerle inaceptable que se pretendiera el bien público a través de una disposición anacrónica, que conllevaba, al fin y a la postre, por evanescente que fuese ya entonces, vasallaje, monopolios señoriales y, con frecuencia, pensiones enfiteúticas muy onerosas sobre tierras por roturar o suelos de aprovechamiento agrícola marginal puestos en cultivo con el esfuerzo exclusivo de los enfiteutas ${ }^{42}$.

\section{Impronta en la red municipal valenciana}

A diferencia de las universidades alfonsinas con mayores efectivos demográficos, los lugares de igual jurisdicción tenían por denominador común, con pocas salvedades, términos reducidos y vecindarios cortos,

${ }^{41}$ Martínez-Santos Isern, V.: Cara y cruz de la sedería valenciana (siglos XVIII y XIX). Valencia, Inst Alfonso el Magnánimo, 1981, p. 156.

${ }^{42}$ Gil Olcina, A.: «Valoraciones, circunloquios y silencios de Antonio Josef Cavanilles sobre el régimen señorial valenciano», Cuadernos de Geografía, 1997, núm. 62, pp. 323328. 
si bien ambos extremos no se hallaban, necesariamente, en relación directa; así, pequeños lugares en la Vega Baja del Segura contaban, a finales del Antiguo Régimen, con censos notoriamente más numerosos que los de la Tinença de Benifassá en el antiguo término general de Morella, muy superiores en superficie, pero de escasas aptitudes agrícolas, a causa de su relieve anfractuoso, suelos poco fértiles y duros inviernos. Contados eran los lugares alfonsinos que excedían de 3.000 ha., casi todos bajaban de 2.000 , muchos de 1.000 y no eran infrecuentes los de menos de 500 ha; algunos de ellos no llegaban a 200 ha., y, como caso extremo, Venta o Lugar Nuevo de Emperador no pasa de 3 ha, y es hoy, a mucha distancia, el menor de los municipios valencianos. Esta diversidad de superficies dependía, fuera de otras variables más específicas, de las posibilidades de cultivo y de la propia antigüedad del lugar, ya que, aún con excepciones, los menos extensos solían ser los ubicados en áreas de regadíos y de fundacion más reciente, evidenciando la transformación en señoríos, mediante el Fuero de 1329, de importantes propiedades agrícolas. También era en éstos donde la correspondencia espacial entre los elementos solariego y jurisdiccional era total, aunque no sólo en eīlos, por tratarse de un hecho frecuente en esta clase de señoríos; y en todo caso, si ambos elementos no se superponían por completo, el primero no iba, por lo general, muy a la zaga del segundo. De ahí que, al producirse la disolución del régimen señorial, muchos de los pequeños municipios con pasado de señores alfonsinos pertenecían a un solo propietario o, a causa de la supresión de mayorazgos, se repartían entre unos pocos miembros del linaje que había ostentado la indicada jurisdicción hasta la promulgación del decreto de Cortes de 6 de agosto de 1811. Por ello, en el transcurso del siglo XIX, y para algunos todavía en éste, los ayuntamientos correspondientes quedaron mediatizados por los propietarios de los términos, auténticos cotos redondos, o hubieron de luchar por sacudirse este poder fáctico. Como se ha indicado, el decreto de 6 de agosto de 1811 abolió también las jurisdicciones alfonsinas; con ello, los señoríos de esa naturaleza, por lo general, tornaron a ser grandes fincas rústicas, cuya legitimidad de origen no podía ser legalmente cuestionada. Así, como ejemplo prototípico, el Resumen hecho por la Junta Consultiva Agronómica de las Memorias sobre Riegos, en 1904, señalaba que «la propiedad territorial está muy dividida en toda la provincia, si se exceptúa la huerta de Orihuela, donde existen algunas fincas que ocupan todo un término; como, por ejemplo, el de Formenera, que pertenece al 

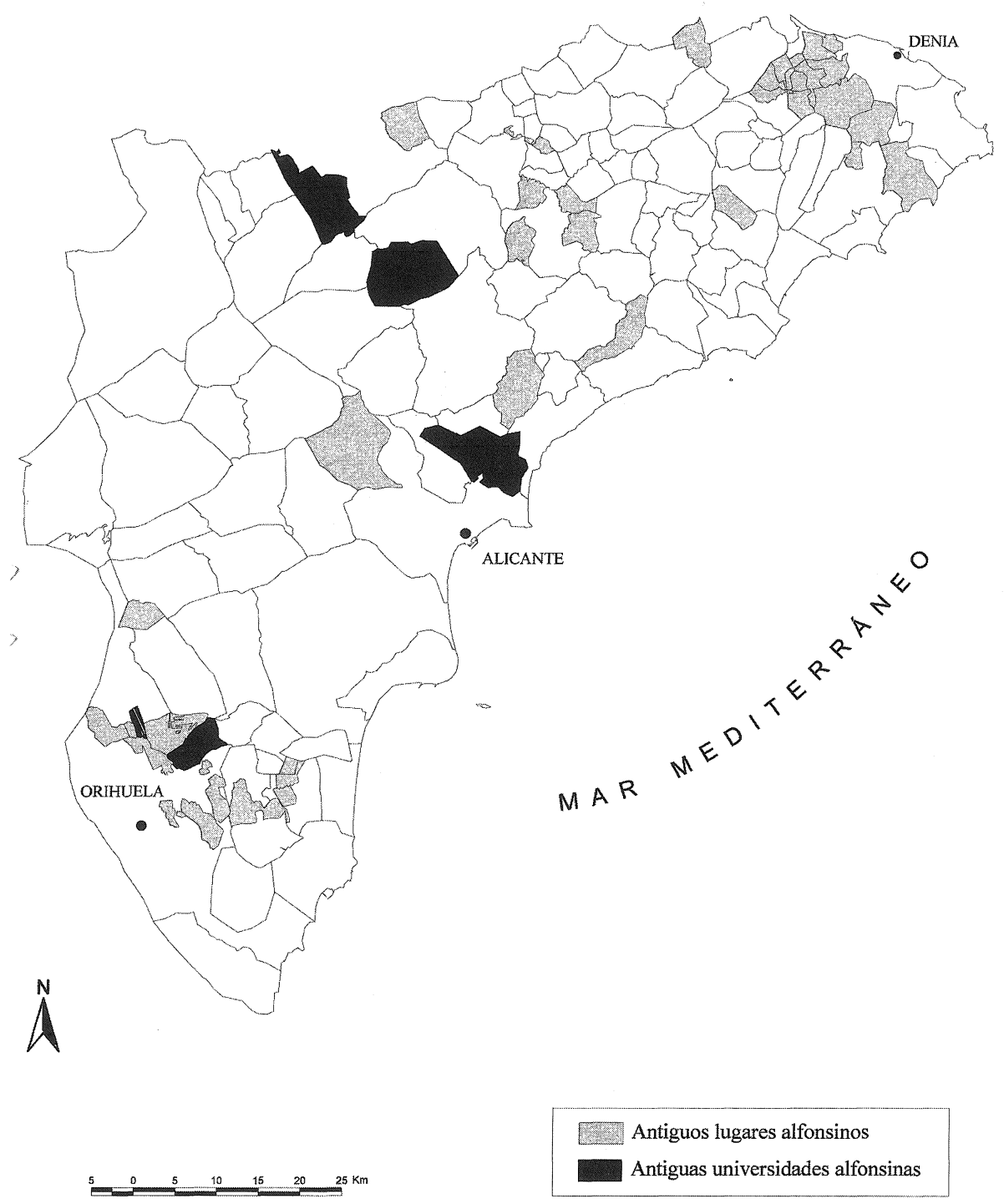

Fig. 2.-Provincia de Alicante. Antiguos lugares y universidades alfonsinas. 
marqués del Bosch, el de Jacarilla, del barón de Petrés; el de Rocamora, del conde de Vía-Manuel, y el de Algorfa, del marqués de igual título, pero estas propiedades sólo en parte son llevadas por sus dueños y lo demás está repartido entre un número mayor o menor de renteros» ${ }^{43}$. Esta situación se mantenía, con pocas modificaciones, al confeccionarse en 1932 el Registro de la Propiedad Expropiables.

Son todas ellas referencias que, ineludiblemente, han de ser tenidas en cuenta y valoradas para explicar la evolución de los municipios de raigambre alfonsina y la desaparicion, por incorporación a uno colindante o fusión con otros, de algunos de ellos.

El trascendental decreto de 6 de agosto de 1811, que comenzaba declarando «incorporados a la Nación todos los señoríos jurisdiccionales, de cualquier clase y condicion que sean», disponía asimismo el cese de corregidores, alcaldes mayores y empleados señoriales, a excepción de ayuntamientos y alcaldes ordinarios, mantenidos por lo que restaba de año. Así, los lugares alfonsinos, que contaban con alcaldes ordinarios de señorío, fueron transformados en términos de realengo. Unos meses después, la constitución de 1812 establecía, en su art. 310, que «Se pondrá Ayuntamiento en los pueblos que no tengan, y en que convengan lo haya», y necesariamente en aquellos que por sí o con su término llegaran a 1.000 almas; y, en desarrollo del mencionado artículo, el decreto de 23 de mayo de 1812 autorizaba a cualquier pueblo carente de ayuntamiento, aunque no reuniese el millar de habitantes, a solicitar, con base en sus circunstancias particulares de agricultura, industria o población, la formación de aquél. Esta primera constitución, «que había rehuido dar una definición ex lege del municipio, optó por expresar un concepto legal y abstracto del mismo, fundado en el pueblo o conjunto de familias que habitan un espacio definido o tienen relación de vecin$\operatorname{dad} »^{44}$

Innecesario resulta encarecer que la legislacion municial reflejo fiemente los avatares políticos del reinado de Fernando VII ${ }^{45}$. Fallecido éste, el efímero Real Decreto de 23 de julio de 1835, a pesar de tratarse

${ }^{43}$ Ministerio de Agricultura, Industria, Comercio y Obras Públicas (Dirección General de Agricultura): El regadío en España (resumen hecho por la Junta Consultiva Agronómica de las Memorias sobre riegos remitidas por los Ingenieros del Servicio Agronómico Provincial), Madrid, 1904, p. 161.

${ }_{44}$ Entrena Cuesta: Curso de Derecho Administrativo. Madrid, Tecnos, 1976, p. 333.

45 Entrena Cuesta, op. cit., 44, pp. 333-337. 
de una norma muy conservadora, elaborada al amparo del estatuto real, introdujo algunos cambios. A los efectos que ahora interesan, confirmó a todos los ayuntamientos existentes, aunque su población no alcanzase el centenar de vecinos, que era el caso de buena parte de los más de doscientos lugares alfonsinos reconvertidos en municipios de realengo; dicha cifra se reduciría progresivamente hasta la actualidad, en que aún pasan del centenar. Esta evolución se ha producido a través de las fusiones de minúsculos municipios o de su agregación a otros mayores, y ha venido motivada por la exigencia de un vecindario creciente, planteamiento acorde con los presupuestos municipales en fuerte aumento para atender la notoria ampliación de atribuciones, obligaciones y servicios.

En este orden de cosas, es de recordar la Ley de Ayuntamientos de 8 de enero de 1845 , cuyo art. 70 suprimía los ayuntamientos de poblaciones que no pasaran de 30 vecinos; y en ejecución del mismo, el real decreto de 25 de enero de 1845 mandaba consultar la voluntad de los municipios afectados «para saber á cuál quieren agregarse» ${ }^{46}$. Como se ve, el mínimo de vecindario requerido para la pervivencia de ayuntamientos y municipios duplica al que había sido necesario para constituir lugares alfonsinos. Un número apreciable de estos antiguos señoríos tuvieron, entonces, que optar por la fusión o agregación, proceso que, muy condicionado por las posibilidades agrícolas y situación del campesinado en cada término, se dejó sentir de forma dispar en las comarcas que concentraban los municipios de referencia; así, mientras, por exceder en todos los casos el vecindario exigido, perduraron en los regadíos intensivos del Bajo Segura y La Safor, dejaron, en cambio, de existir varios de ellos, por agregación o fusión, en el área de Játiva y Alto Maestrazgo. Por ejemplo, en el antiguo término general de Morella, al «no tener el pueblo de Corachá los 30 vecinos que marca la última ley de ayuntamientos, se ha instruido el oportuno expediente a fin de agregarlo a Bojar, lo mismo que Fredes, para que los tres formen una sola municipalidad» ${ }^{47}$. También, por esos años, el término de Surió fue incorporado al de Játiva; y, en idéntico sentido, se hacía constar que el Ayuntamiento de Manuel «in-

${ }^{46}$ Martínez Alcubilla, M. et al.: Diccionario de la administración española. Madrid, Imp. del Asilo de Huérfanos del S. Corazón de Jesús, 1868, 13 vols. + apéndices anuales 1868-1972.

47 Madoz, P.: Diccionario Geográfico-Estadístico de España y sus Posesiones de Ultramar. Madrid, VI, p. 573. 


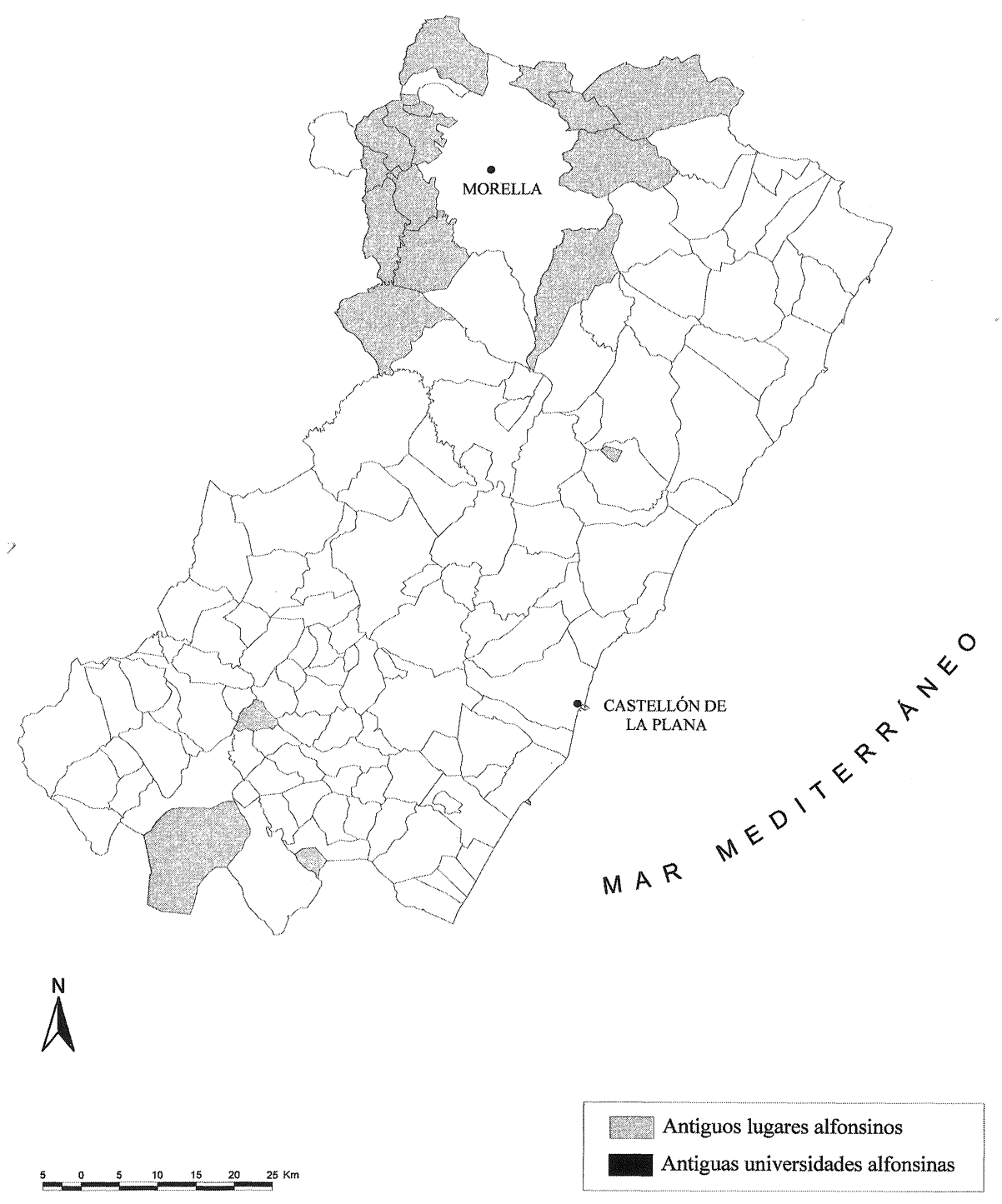

Fig. 3.-Provincia de Castellón. Antiguos lugares y universidades alfonsinos. 
cluye todo lo perteneciente a Abat, Faldeta y Torreta, que con él forman una sola municipalidad» ${ }^{48}$. Curiosamente escapó a la supresión ordenada por la Ley de 8 de enero de 1845 la ya citada Venta o Lugar Nuevo de Emperador, único señorío alfonsino carente de terrazgo, nacido en torno a la destilería de aguardiente y fábrica de lonas instaladas casi un siglo atrás, hacia 1760, por Agustín Emperador, en término de Museros, encomienda de la Orden de Calatrava; y sobrevivio como lugar con auntamiento, aunque, según informa el corresponsal de Madoz, sólo tenía « 24 casas y 3 barracas colocadas en línea recta y sin que formen calles; entre las que se cuenta la del Sr. Territorial... Carece de término; pues aunque ha conseguido recientemente formar por sí solo municipalidad desmembrándose de Museros, no se extiende su jurisdicción a más que a el caserío del que es dueño absoluto el señor», indicado, además, que su población era de 27 vecinos y $130 \operatorname{almas}^{49}$.

En abierto contraste con los referidos términos del Alto Maestrazgo y La Costera, el minúsculo de Molins, en plena Huerta de Orihuela, y cuyo núcleo fueron 75 ha de regadío, contaba, hacia 1847 , con «15 casas que forman cuerpo de pobl., con otras 15 en el campo y más de 20 barracas ... el terreno es feracísimo, todo de regadío, que se fertiliza con aguas del río Segura...» ${ }^{50}$. Sin olvidar la Ley de Ayuntamientos progresista de 5 de julio de 1856, el ulterior restablecimiento de la Ley de 8 de enero de 1845 ni las disposiciones posteriores de 1863, 1864 y 1866, ha de resaltarse la importancia de la Ley municipal de 20 de agosto de 1870, que, con las modificaciones introducidas por la de 16 de diciembre de 1876, rigió el municipio de la Restauración hasta la entrada en vigor, por Decreto-Ley de 8 de marzo de 1924, del Estatuto municipal, obra de Calvo Sotelo. Del contenido de la expresada norma sobresalen, en cuanto al tema considerado, sus cinco primeros artículos, y en especial el segundo, cuyo contenido es el siguiente: «Es término municipal el territorio á que se extiende la acción adminisrativa de un Ayuntamiento. Son circunstancias precisas en todo el término municipal: $1 .^{\mathrm{a}}$ Que no baje de 2.000 el número de sus habitantes residentes. 2. ${ }^{a}$ Que tenga o se le puede señalar un territorio proporcionado a su población. 3. ${ }^{\mathrm{a}}$ Que pueda sufragar los gastos municipales obligatorios con los recursos que las leyes

${ }^{48}$ Madoz, op. cit., IX, p. 600

${ }^{49}$ Madoz, op. cit., VII, p. 473.

50 Madoz, op. cit., XI, pp. 469-470. 


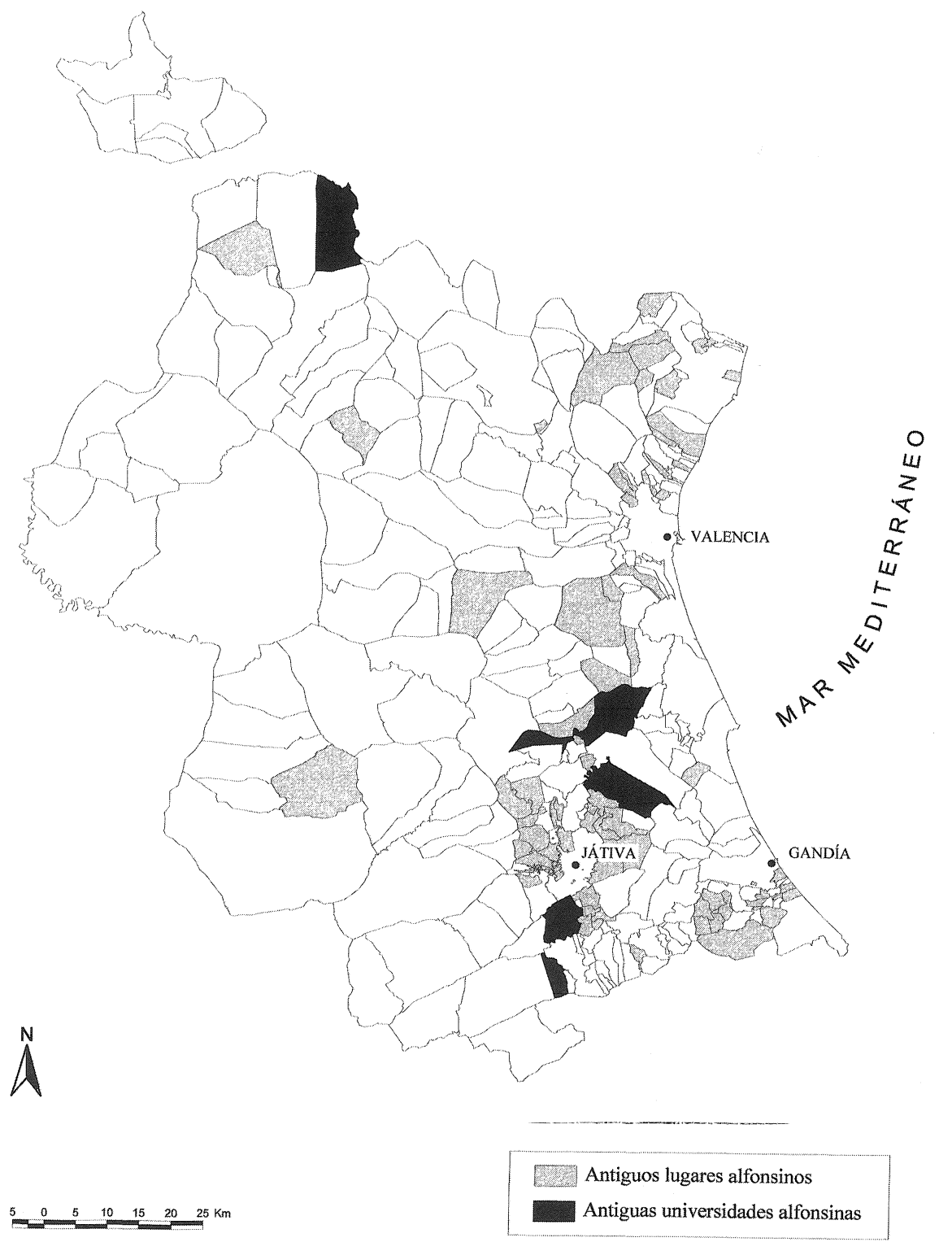

FIG. 4.-Provincia de Valencia. Antiguos lugares y universidades alfonsinos. 
autoricen. Subsistirán, sin embargo, los actuales términos municipales que tengan Ayuntamiento, aun cuando no reúnan las circunstancias anteriores.» Por tanto, no se disponía la supresión de municipios por escasez de vecindario, aunque si se rechazaba implícitamente la creación de los que no tuviesen el mínimo de residentes requerido, poniéndolo como condición de viabilidad; innecesario resulta encarecer que, por entonces, la gran mayoría de antiguos lugares alfonsinos no llegaban a esa cifra. Pero si no se imponía la desaparición de pequeños municipios, no por ello es menos cierto la existencia de un motivo real para que éste se produjera, ante la imposibilidad en que se hallaron muchos de los referidos términos para hacer frente a los gastos crecientes originados por las obligaciones, funciones y servicios municipales establecidos; de ahí que la cifra de aquéllos se redujese sustancialente en el transcurso del prolongado período de vigencia, más de medio siglo, de la Ley municipal de 1870.

El censo de Godoy (1797), como referencia inicial, el Diccionario de Madoz medio siglo después, y luego, ya en época estadística, los censos correspondientes, desde 1856, permiten seguir el proceso de desaparición, como lugares con ayuntamiento, por agregación o fusión, de antiguos señoríos alfonsinos, debido a su escaso vecindario e inviabilidad funcional. Otros, en cambio, han corrido mejor suerte, ya que, en la actualidad, pasan del centenar los municipios de ese origen. Como se ha reiterado, las representaciones de los mismos en los mapas de las tres provincias pecan, con seguridad, y bastante, por defecto, pero ello no es sino un dato más a favor de encarecer la singular trascendencia del fuero alfonsino en el poblamiento, configuración de la red municipal y organización del territorio valenciano.

Aunque los ejemplos de fragmentación de términos generales a través del fuero alfonsino, mediante la creación de señoríos o segregación de universidades, son múltiples, es cierto que algunos, con huellas elocuentes y llamativas en el mapa municipal de la Comunidad Valenciana, revisten carácter prototípico. Son los casos de Játiva y Orihuela como grandes términos de realengo, de Gandía y Denia en calidad de estados nobiliarios de primer orden, y de Alcira, cuya singularidad obedece a ostentar la primacía cronológica y numérica en la erección de universidades alfonsinas.

Un breve análisis comparado de Játiva y Orihuela muestra evidentes similitudes. En principio, por la función administrativa de ambas ciu- 
dades, la primera como cabecera de subgobernación y bailía y Orihuela como capital de la gobernación meridional del reino; una y otra contaron con dilatados términos generales y asimismo con nutrido e influyente patriciado urbano, al que es preciso añadir la pujanza de las instituciones religiosas, que condujo a Játiva, patria de los dos papas Borja, a la pretensión de convertirse en sede de obispado, a la postre frustrada por la oposición de Valencia, y a Orihuela, en cambio, a conseguirla; baste recordar que en esta última ciudad tanto el cabildo catedralicio como el Colegio de Santo Domingo de Orihuela fueron titulares de sendos señoríos alfonsinos, al igual que en Játiva el lugar de Abad perteneció a la Colegiata y fue señorío la llamada Torre de los Frailes. No faltan, empero, diferencias, particularmente que la proliferación de señoríos alfonsinos en el área de Játiva, sin duda relacionada con el hábitat de época musulmana, es anterior a la que se produce durante la Edad Moderna en el Bajo Segura, donde fue preciso acometer bonificación de aguazales, defenderse de las desastrosas avenidas del segura y expandir el doble sistema de circulación de aguas vivas y muertas.

Mayor es, si cabe, la semejanza entre ducado de Gandía y marquesado de Denia, con el hecho compartido de que la titularidad de los señoríos de jurisdicción alfonsina no correspondía sólo al patriciado urbano de ambas ciudades, sino también a linajes nobiliarios encumbrados, como eran respectivamente en un caso y otro, los marqueses de Aytona y de Guadalest. Por último, en el término general de Alcira se registró la primera segregación de universidad con jurisdicción alfonsina, que fue Algemesí (1574), a tenor del decreto de Felipe II que comenzaba «Sacra Catholica Real Magestad: Bernat Guinovart, Sindich de Algemesí presenta V Magestad los capitols desus scrits a effecte que lo dit poble de Algemesí de ara en avant sia universitat distinta y separada de la villa de Alzira y tinga govern, regiment y administració de per si jurisdicció civil y criminal en los modos $\mathrm{y}$ forma seguents...», y de igual forma se produjeron las separaciones de Carcagente (1576) y Guadasuar (1581). Sin duda, este proceso guarda estrecha conexión con el incremento de los citados núcleos de población merced a las excelentes posibilidades agrícolas del llano de inundacion del Júcar. 


\section{BIBLIOGRAFÍA}

Alberola Romá, A. (1984): Jurisdicción y propiedad de la tierra en Alicante (ss. XVII y XVIII). Alicante, Univ. de Alicante, $547 \mathrm{pp}$.

_- (1989): «Los señoríos alfonsinos en el sur del País Valenciano. Aproximación a su estudio,» Senorío y feudalismo en la Península Ibérica (siglos XII al XIX), Zaragoza.

ARDIT LuCAS, M. (1977): Revolución liberal y revuelta campesina. Un ensayo sobre la desintegración del régimen feudal en el País Valenciano (1793-1840) Barcelona, Ariel, $547 \mathrm{pp}$.

BAS et GALCERÁN, N. (1960): Theatrum Iurisprudentiae Forensis Valentineae, Pars Prima, Valencia, Ex Typ. Laurentii Mesnier.

Beneyto PÉReZ, J. (1936): «Un opúsculo jurídico de Jaffer». Bol. Soc. Castellonense de Cultura, vol. XVII, pp. 69-81.

Bernabé GIL, D. (1982): Tierra y Sociedad en el Bajo Segura (1700-1750). Alicante, Univ. de Alicante, $233 \mathrm{pp}$.

_ (1986): «La formación de un patrimonio nobiliario en el seiscientos valenciano. El primer marqués de Rafal,» Rev. $H^{a}$. Moderna, Univ. de Alicante, núm. 5. pp. 11-66.

— (1993): «Universidades y villas. Notas sobre el proceso de segregación municipal en el Realengo valenciano (ss. XVI y XVII)», Rev. $H^{a}$. Moderna, Univ. de Alicante, núm. 12. pp. 11-38.

_ (1989): «Sobre el origen territorial en los señoríos valencianos de colonización alfonsina,» Señorío y feudalismo en la Península Ibérica (siglos XII al XIX), Zaragoza.

- (1993): «Una coexistencia conflictiva: municipios realengos y señoríos de su contribución general en la Valencia foral», Rev. $H^{a}$. Moderna, Univ. de Alicante, núm. 2, pp. 11-78.

- (1993): «Realengo y señorío en el proceso disgregador de los grandes municipios valencianos. Un análisis comparativo (ss. XVI y XVII)», en Actes del Tercer Congrés d'Història Moderna de Catalunya, Institucions Catalanes, Barcelona, pp. 381-392.

Canales Martínez, G. (1981): «Creación del señorío eclesiástico de Bigastro (19671715)», La propiedad de la tierra en España. Alicante, Univ. de Alicante, pp. 65-74.

Canales Martínez, G. y MarTínez García, I. (1994): El señorío eclesiástico de Bigastro (siglos XVIII-XIX), Alicante, Inst. de Cultura «Juan Gil-Albert», 304 pp.

CANDEla Hidalgo, A. R. (1992): La extinción del elemento solariego en los señoríos de jurisdicción alfonsina radicados en las comarcas del Campo de Alicante y Bajo Vinalopó, Memoria de Licenciatura inédita, Univ. de Alicante.

Decisionum don Francisci Hieronymi de LeOn. Valentiae Ex Praelo Sylvestri, in vico scapharum, 1646.

DueÑAS MOYA, M. ${ }^{a}$ DEL C. (1997): Territorio y jurisdicción en Alicante: el término general durante la Edad Moderna. Alicante, Conselleria de Cultura, Educación i Ciència, 326 pp.

Entrena Cuesta (1976): Curso de Derecho Administrativo. Madrid, Tecnos, 5, a ed.

Escolano, G. (1972): Década primera de la historia de la Insigne y Coronada Ciudad y Reyno de Valencia, 1610 (facsímil, Univ. de Valencia.

Furs e ordinations fetes per los gloriosos Reys de Aragó als regnicols del Regne de Valencia (1977) (facsímil, Univ. de Valencia, pról. de J. García González).

GaLlEgo ANABITARTE, A. (1969): «Notas histórico-jurídicas sobre Régimen local español», $R E V L$, núm. 166, pp. 265-274.

GIL OlcinA, A. (1979): La propiedad señorial en tierras valencianas. Valencia, Del Cenia al Segura, $276 \mathrm{pp}$.

(1983): «La propiedad de la tierra en los señoríos de jurisdicción alfonsina», Inv. geográficas, núm. 1, pp. 7-24. 
_ (1986): «Jurisdicción alfonsina y poblamiento valenciano», Cuadernos de Geografía, Univ. de Valencia, núm. 39-40, pp. 235-245.

- y Canales Martínez, G. (1988): Residuos de propiedad señorial en España. Perduración y ocaso en el Bajo Segura. Alicante, Inst. de Cultura «Juan Gil-Albert», 411 pp.

Giménez LóPEz, E. (1993): «Fuero alfonsino y Fuero de Población de Sierra Morena en los proyectos de colonización de la Corona de Aragón en la segunda mitad del siglo XVIII», Rev. de H. ${ }^{a}$ Moderna, núm. 12, pp. 141-184.

IBORRA LERMA, J. M. (1981): Realengo y señorío en el campo de Morvedre. Sagunto.

Mateu SAnZ, L. (1655): Tractatus de regime urbis et regni Valentiae. Valencia, Bernardo Nogués.

Millán GaRcía-VARela, J. (1984): Rentistas y campesinos. Desarrollo agrario y tradicionalismo político en el Sur del País Valenciano, 1680-1840. Alicante, Inst. de Cultura «Juan Gil-Albert», 451 pp.

Moxó, S. (1965): La disolución del régimen señorial en España. Madrid, C.S.I.C., 271 pp.

Mateu Ripoll, V. y Caballero Segarra, J. (1998): «Las nuevas poblaciones en España durante el siglo XviII: el caso de Alicante», en Cuadernos de I.N.I.C.E., núms. 22/24, pp. 27-44.

Pla Alberola, P.: «Apuntes para el estudio de las rentas señoriales en el siglo XVI. Los pequeños señoríos del «Quartel de las Montañas», Jerónimo Zurita. Su época y su escuela (Congreso Nacional, Fundación «Institución Fernando el Católico», Dip. Prov. de Zaragoza.

- (1987): «Recolonización interior y expansión del régimen señorial. La carta puebla de la Sarga de 1774», Estructuras y regímenes de tenencia de la tierra en España. Madrid, MAPA, pp. 117-128.

—_ (1993): «La Jurisdicción Alfonsina como aliciente para la recolonización del territorio», Rev. de Historia Moderna, núm. 12, pp. 79-140.

- (1998): «El desmantelamiento del poder político de los señores valencianos en los siglos XVI y XVII», España y Suecia en la época del barroco (1600-1660). Congreso Internacional. Actas. Madrid, Consellería de Educación y Cultura, 1998, pp. 73-99.

Romeu Alfaro, S. (1972): «Los Fueros de Valencia y los Fueros de Aragón: Jurisdicción Alfonsina», Anuario de Historia del Derecho Español, pp. 75-115.

VicIana, M. DE (1972-1983): Crónica de la Ínclita y Coronada Ciudad de Valencia (Reimpresión facsímil de la edición de 1564. Estudio preliminar e índices por Sebastián García Martínez), Valencia, 5 vols.

RESUMEN: Acordado y otorgado en las Cortes valencianas de 1329, el Fuero Alfonsino, que creó la jurisdicción de igual nombre, tuvo vigencia durante más de cuatrocientos años, al ser el único de los Furs reinstaurado, en 1772, tras la abolición general de 1707. Auspició la fundación o el fortalecimiento de multitud de lugares e, incluso, la segregación de algunas universidades.

Por todo ello constituye referencia obligada y de primer orden a la hora de interpretar el poblamiento, red municipal y organización administrativa del territorio valenciano.

PALABRAS ClAVE: Fuero alfonsino, lugares alfonsinos, universidades alfonsinas, fragmentación de términos generales, municipios valencianos.

ABSTRACT: The Alfonsinian charter, agreed and granted in the Valencian Parliament of 1329 , which established the jurisdiction with the same name, was in force for more than four hundred years, as it was the only Fur re-established in 1772 , after the general 
abolition in 1707. It forested the establishment or the strengthening of a enourmous variety of places and even the segregation of some universities.

All the same, it is an obligatory and basic reference when it comes to interpreting the settlement, local network and administrative organisation of the Valencian territory.

KEY wORDS: Alfonsian charter, Alfonsian places, Alfonsian universities, fragmentation of general terms, Valencian municipalities.

RÉSumé: Approuvé et concédé par les Cours valenciennes de 1329, le «Fuero alfonsino», à l'origine de la jurisdiction du même nom, est resté en vigueur durant plus de quatre cents ans, étans le seul «Fur» restauré en 1772 après l'abolition générale de 1707. Il a protégé la fondation ou le reforcement d'une multitude de localités, ainsi que la ségrégation de certaines universités.

Voilà pourquoi il constitue una référence obligatoire et de premier ordre pour interpréter le peuplement, le réseau municipal et l'organisation administrative du territoire valencien.

MOTS-CLÉS: «Fuero alfonsino», localités alphonsines, universités alphonsines, fragmentation de termes généraux, municipalités valenciennes. 